\title{
NUTRITIONAL ASPECTS OF SIX QUINOA (Chenopodium quinoa WILLD.) ECOTYPES FROM THREE GEOGRAPHICAL AREAS OF CHILE
}

\author{
Margarita Miranda ${ }^{1}$, Antonio Vega-Gálvez ${ }^{*}$, Issis Quispe-Fuentes ${ }^{1}$, María José Rodríguez ${ }^{1}$, \\ Héctor Maureira², and Enrique A. Martínez ${ }^{3}$
}

\begin{abstract}
This study explored the diversity of the quinoa crop in Chile from a nutritional perspective. Nutritional properties, minerals, vitamins, and saponin content were assessed in seeds of six Chilean quinoa (Chenopodium quinoa Willd.) ecotypes grown in three main production areas with distinctive climatic and edaphic conditions: Ancovinto and Cancosa in the NorthAltiplano or High Plateau, Cáhuil and Faro in the central coastal area, and Regalona and Villarrica in the south of the country. There were significant differences $(\mathrm{P}<0.05)$ in all the nutritional properties of the quinoa seeds in all three areas. Quinoa of the Villarrica ecotype showed the highest protein content $\left(16.10 \mathrm{~g} 100 \mathrm{~g}^{-1} \mathrm{DM}\right)$ and the highest content of vitamins E and $\mathrm{C}\left(4.644 \pm 0.240\right.$ and $23.065 \pm 1.119 \mathrm{mg} 100 \mathrm{~g}^{-1} \mathrm{DM}$, respectively). The highest content of vitamins B1 $(0.648 \pm 0.006 \mathrm{mg}$ $\left.100 \mathrm{~g}^{-1} \mathrm{DM}\right)$ and B3 (1.569 $\left.\pm 0.026 \mathrm{mg} 100 \mathrm{~g}^{-1} \mathrm{DM}\right)$ was found in the Regalona ecotype, while the highest value of vitamin B2 $\left(0.081 \pm 0.002 \mathrm{mg} 100 \mathrm{~g}^{-1} \mathrm{DM}\right)$ occurred in the Ancovinto ecotype. Potassium was the most abundant mineral with a

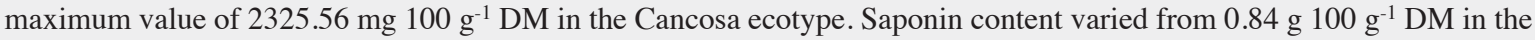

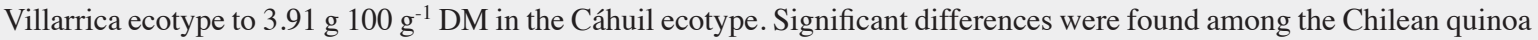
ecotypes grown under different climatic conditions; however, all the quinoa seeds exhibited a high nutritional value. These results are compatible with the genetic differences previously observed in the three geographical areas under study. Thus, if more studies are conducted to show the particular properties of quinoa from specific areas, it would be possible in the future to coin the term "controlled designation of origin" (appellation d'origine contrôlée) and add commercial value to Chilean quinoa seeds in the domestic and international markets.
\end{abstract}

Key words: Quinoa, vitamins, minerals, saponin content, nutritional properties.

$\mathrm{N}^{\circ}$ ew paradigms of world food and agriculture aim to show finer nutritional and functional properties of foods for human consumption, which go beyond traditional sanitary requirements and good agricultural practices. Moreover, chronic hunger is another world challenge. According to the Food and Agriculture Organization (FAO), between 2009 and 2010, just before the outbreak of the hunger crisis in Somalia, 925 to 1023 million people in the world were suffering chronic hunger; this situation was declared unacceptable since these were the FAO's highest records since the early 1970s (FAO, 2011). One way of addressing solutions for this tremendous issue, but also to the requirements for better quality foods, is to look for crops that are nutritionally rich and can also grow under stressful environmental and

\footnotetext{
${ }^{1}$ Universidad de La Serena, Facultad de Ingeniería, Av. Raúl Bitrán s/n, Box 599, La Serena, Chile.

*Corresponding author (avegag@userena.cl).

${ }^{2}$ Universidad de La Serena, Laboratorio Central de Análisis, Cisternas Esq. Anfión Muñoz s/n, La Serena, Chile.

${ }^{3}$ Centro de Estudios Avanzados en Zonas Áridas CEAZA, Av. Raúl Bitrán s/n, La Serena, Chile.

Received: 21 October 2011.

Accepted: 23 May 2012.
}

climatic conditions typical of the world hunger areas, such as East Africa. The astonishing nutritional quality of some new world crops, among which species of the genus Amaranthus are also considered (Capriles et al., 2008; Vega-Gálvez et al., 2010), have the additional benefit of being able to withstand extreme climatic and soil conditions (Martínez et al., 2009). This has also raised their potential use as sources of new grains in the fight against hunger. In recent years, the cultivation of crops such as quinoa (Chenopodium quinoa Willd.) has gained increasing attention due to the attractive nutritive value of its grains, as well as an effort to expand the number of species which contribute to human nutrition (Ruiz and Bertero, 2008; Hirose et al., 2010). The outstanding nutritional and functional properties of quinoa seeds will be promoted by the FAO in 2013 since the United Nations has declared that year as the international year of quinoa. Such properties include higher protein content than traditional cereals and the presence of the complete set of both dispensable and indispensable (essential) amino acids. This is particularly relevant since the production of meat proteins causes an extremely high water footprint (Chapagain and Hoekstra, 2008). Quinoa grains also have vitamins $\mathrm{C}, \mathrm{E}$ (tocopherols), and B complex, and 
important minerals ( $\mathrm{Ca}, \mathrm{K}, \mathrm{Fe}, \mathrm{Mg}, \mathrm{Mn}, \mathrm{P}$ ), isoflavons, and high quality lipids. Such a combination of factors contributes to excellent antioxidant properties and even the saponins in the seed coats, previously considered as antinutrients, can now be extracted for industrial and biomedical use (Jancurová et al., 2009; Vega-Gálvez et al., 2010).

Beyond the highly beneficial nutritional properties of this plant is its extreme agro-ecological adaptability. The nutritional composition of quinoa varies among ecotypes due to strong genetic variability in addition to environmental differences in the Andean region (RepoCarrasco-Valencia et al., 2010). Similar effects in potato and wheat ecotype composition due to agricultural practices, agroclimatic factors, and soil types have already been reported (Barikmo et al., 2004; Thybo et al., 2006; Galdón et al., 2010). Quinoa varies in Bolivia, Peru, and Ecuador, and can be grown from Colombia to the southern regions of Argentina and Chile as a result of a long-lasting domestication process (Fuentes et al., 2009; 2012). This diversity can be the basis for possible adaptations in the fight against hunger in countries facing similar challenges of drought and salinity under a very diverse array of soil and climatic conditions, for example, in India (Bhargava et al., 2006).

The long Chilean mainland territory between $18^{\circ}$ and $43^{\circ} \mathrm{S}$ lat (stretching over $3000 \mathrm{~km}$ ) offers an extended natural laboratory to test environmental effects on the nutritional properties of quinoa. Quinoa has been cultivated within this latitudinal distribution since ancient times. Three different biogeographic regions or genetic pools of quinoa are now recognized in Chile, the North-Altiplano, the Center, and the South (Fuentes et al., 2009). Therefore, in this study the seeds of different quinoa ecotypes from Chile's three production areas were assessed for their nutritional properties, minerals, vitamins, and saponin content; furthermore, different climatic and soil conditions of the three geographical areas were studied to observe if they had any effect on the abovementioned properties.

\section{MATERIALS AND METHODS}

\section{Origin of quinoa seeds and sample preparation}

The quinoa seeds were harvested from the three ancestral production areas in Chile, including samples from the three genetic pools (North-Altiplano at $3500 \mathrm{~m}$ a.s.1., Center, and South at sea level or low altitude cultivation areas). A total of six quinoa ecotypes were chosen: two North-Altiplano ecotypes from the two localities of Ancovinto and Cancosa (approximately $19^{\circ} \mathrm{S}$ lat); two Center ecotypes from Cáhuil and Faro (approximately $34^{\circ}$ S lat); and two South ecotypes from Villarrica (locality approximately $39^{\circ} \mathrm{S}$ lat) and La Regalona (official variety recorded in a national catalogue of the SAG division of the Chilean Ministry of Agriculture). Samples were analyzed without the industrial dehusking treatment (a process that needs hundreds of $\mathrm{kg}$ of seed to be run); they were therefore only visually inspected to discard contaminant particles or impurities. Analytical determinations were carried out on quinoa seeds ground with a grinder (MC0360, UFESA, Zhejiang, China).

\section{Experimental analytical procedures}

The following were determined: moisture content by the Association of Official Analytical Chemists AOAC method $\mathrm{N}^{\circ} 934.06$ (AOAC, 1990); crude protein content by the Kjeldahl method with a conversion factor of 6.25 (AOAC $\mathrm{N}^{\circ}$ 960.52); lipid content by gravimetric measurement following Soxhlet extraction (AOAC $\mathrm{N}^{\circ}$ 960.39); crude fiber by acid/alkaline hydrolysis of insoluble residues (AOAC $\mathrm{N}^{\circ}$ 962.09); and crude ash content by incineration in a muffle furnace at $550{ }^{\circ} \mathrm{C}$ (AOAC $\mathrm{N}^{\circ}$ 923.03). All the methodologies followed the recommendations of AOAC (1990). The $\mathrm{pH}$ was measured with an EXTECH Instruments microcomputer $\mathrm{pH}$ vision 246072 (Waltham, Massachusetts, USA) (AOAC $\mathrm{N}^{\circ}$ 981.12), and the titrimetric acidity level of ground grains was measured following the method indicated by AOAC ( N $^{\circ}$ 925.53) (AOAC, 1990), which was expressed as sulfuric acid. Water activity $\left(\mathrm{a}_{\mathrm{w}}\right)$ was measured at 25 ${ }^{\circ} \mathrm{C}$ with a water activity meter (Novasina, model TH500, Pfäffikon, Lachen, Switzerland). Mineral elements ( $\mathrm{Na}, \mathrm{K}, \mathrm{Ca}, \mathrm{Mg}, \mathrm{Cu}, \mathrm{Mn}, \mathrm{Zn}$, and $\mathrm{Fe}$ ) were measured with an atomic absorption spectrophotometer (AAS; Shimadzu Instruments, Inc., SpectrAA-220, Kyoto, Japan) after digestion with a mixture of $\mathrm{H}_{2} \mathrm{SO}_{4}, \mathrm{HNO}_{3}$, and $\mathrm{HClO}_{4}$. The $\mathrm{P}$ content was estimated by a phosphovanadium-molybdenum complex at $466 \mathrm{~nm}$ (Shimadzu Instruments, Inc., Spectrophotometer UV-120-02, Kyoto, Japan) as described in previous work (Miranda et al., 2010). The mineral contents were expressed in mg 100 $\mathrm{g}^{-1}$ DM. Vitamin C was determined by certification of NBS (N-bromosuccinimide) according to Barakat et al. (1955) with the following modifications: the oxidizing agent (NBS) was standardized by taking a $10 \mathrm{~mL}$ aliquot of a standard ascorbic acid $\left(0.2 \mathrm{mg} \mathrm{mL}^{-1}\right)$ solution which was placed in a flask containing $2 \mathrm{~mL}$ KI (4\%) solution, $0.8 \mathrm{~mL}$ acetic acid (10\%) solution, drops of a starch solution (1\%) as indicator, and $12 \mathrm{~mL}$ of distilled water. This mixture was then titrated with an NBS $\left(0.2 \mathrm{~g} \mathrm{~L}^{-1}\right)$ solution. The process ended when a permanent blue color was observed. To determine ascorbic acid in the samples, $0.2 \mathrm{~g}$ oxalic acid was added, crushed, homogenized, and filtered. The sample solution was placed in an Erlenmeyer flask containing $5 \mathrm{~mL} \mathrm{KI}$ solution, $2 \mathrm{~mL}$ acetic acid solution, drops of starch solution, and $30 \mathrm{~mL}$ distilled water; it was then titrated with the NBS solution. Vitamin C content (mg vitamin C $100 \mathrm{~g}^{-1} \mathrm{DM}$ ) was calculated by Equation [1]:

$$
\text { Vit } C=\left(\frac{2 A A \times B}{T \times M}\right) \times 100
$$


where $\mathrm{T}(\mathrm{mL})$ is the volume of NBS of the standard solution of $2 \mathrm{mg}$ vitamin $\mathrm{C}(\mathrm{AA})$; B $(\mathrm{mL})$ is the volume of NBS corresponding to the sample; and $\mathrm{M}(\mathrm{g})$ is the sample mass.

Vitamin E ( $\alpha$-tocopherol) content was determined by the high performance liquid chromatography (HPLC)/ fluorescence method described by Miranda et al. (2010). Samples were extracted with a methanol-BHT (butylhydroxytoluene) (1 $\left.\mathrm{mg} \mathrm{mL}^{-1}\right)$ solution. Vitamin $\mathrm{E}$ content was expressed in $\mathrm{mg} 100 \mathrm{~g}^{-1} \mathrm{DM}$. Furthermore, vitamin $\mathrm{B}_{1}$ (thiamine), $\mathrm{B}_{2}$ (riboflavin), and $\mathrm{B}_{3}$ (niacin) were determined by acid and enzymatic hydrolysis, separated with different HPLC columns in the appropriate mobile phases, and detections were performed at the respective wavelengths in accordance with AOAC $\mathrm{N}^{\circ}$ 942.23, 970.65, and 961.14 (AOAC, 1995), respectively. Vitamin contents were expressed in $\mathrm{mg} 100 \mathrm{~g}^{-1}$ DM. Saponins were analyzed based on a modified reversed-phase HPLC procedure described by San Martín and Briones (2000). Three grams of grown sample were extracted with an ethanol $50 \% \mathrm{v} / \mathrm{v}(1: 13)$ aqueous solution for $2 \mathrm{~h}$ with constant stirring. Then the extract was centrifuged (Presvac, Argentina) for $20 \mathrm{~min}$ at $20000 \mathrm{rpm}$ and the supernatant dried at $55{ }^{\circ} \mathrm{C}$ for $8 \mathrm{~h}$. The HPLC analyses were done in an Agilent 1100 Series HPLC system that includes a DAD detector set at $210 \mathrm{~nm}$ and an automatic injector. The separation was carried out with a Kromasil C-18 RP column $(250 \times 4.8 \mathrm{~mm}, 5 \mu \mathrm{m})$ at $25^{\circ} \mathrm{C}$. The mobile phase consisted of a $0.1 \%$ formic acid solution in water (A) and acetonitrile (B). A gradient system was then applied starting with a ratio of $75: 25(\mathrm{~A}: \mathrm{B} ; \mathrm{v} / \mathrm{v})$ up to 65:35 (A:B; v/v) for $15 \mathrm{~min}$ with a $0.7 \mathrm{~mL} \mathrm{~min}^{-1}$ constant flow rate. Next, the ratio was changed to 55:45 (A:B; $\mathrm{v} / \mathrm{v}$ ) and the flow rate to $1.0 \mathrm{~mL} \mathrm{~min}^{-1}$ for $20 \mathrm{~min}$. The injected sample volume was $5 \mu \mathrm{L}$ with a concentration of $50 \mathrm{mg} \mathrm{mL}^{-1}$ dry extract. All solvents were of HPLC grade (Merck, Darmstadt, Germany). Results are expressed as g $100 \mathrm{~g}^{-1} \mathrm{DM}$.

\section{Statistical analysis}

All analyses were triplicated. All the data were expressed as mean \pm standard deviation (SD). Analysis of data was performed with Statgraphics Plus 5 (Statistical Graphics Corp., Herndon, Virginia, USA). Significance testing was performed by Fisher's least significant difference (LSD) test; differences were considered statistically significant when $\mathrm{P}<0.05$. The multiple range test (MRT) included in the statistical program was applied to prove that there were homogeneous groups in each of the analyzed parameters. Principal Component Analysis was also performed on the complete set of data (24 different proximal, nutritional, and mineral measurements) in order to give an overall proximity/distance figure for the three different samples of each quinoa seed source studied here.

\section{RESULTS AND DISCUSSION}

\section{Nutritional composition}

The three different quinoa seed origins correspond to a gradient of higher aridity in the northern High Plateau (150-300 $\mathrm{mm}$ annual rainfall) to lesser aridity in the Center (500 $\mathrm{mm}$ annual rainfall), and a rainy region in the South (1000-2000 mm annual rainfall) with a concomitant soil salinity gradient which is also normally higher in the High Plateau region (see detailed description in Ruiz-Carrasco et al., 2011). As expected, the nutritional composition of the six quinoa ecotypes from the three different areas (Table 1) indicated lower moisture content for the northern drier genetic area as compared with the central and southern areas. The highest moisture content was found in the ecotypes of the rainiest region of Villarrica with values similar to those reported by Wright et al. (2002) and Vega-Galvez et al. (2010) for quinoa seeds from other Andean regions. The two central ecotypes (Cáhuil and Faro) are similar for most of the data, except for ash and lipid content. Ecotypes of the northern and southern areas showed the greatest difference $(P<0.05)$, except for ash content. The highest ash content was found in the southern ecotypes (Regalona and Villarrica), an area characterized by soils strongly affected by volcanic activity (Huygens et al., 2008). The ash content of quinoa (3.15-3.65\% DM) is similar to that obtained by Wright et al. (2002) and higher than rice (0.5\%), wheat (1.8\%), and other traditional cereals (Bhargava et al., 2006). The Regalona and Villarrica ecotypes (both from the South) also showed the highest total protein content (14 to 16 g $100 \mathrm{~g}^{-1}$ DM, respectively), which can be due to high $\mathrm{N}$ bioavailability in the southern volcanic soils (Huygens et al., 2008); those from the Center showed the lowest protein content (12 g $\left.100 \mathrm{~g}^{-1} \mathrm{DM}\right)$. The protein content of quinoa from the South is similar to wheat and spelt, whereas for the other areas it is similar to barley, oat and

Table 1. Proximal analysis of six quinoa ecotypes from three geographical areas of Chile.

\begin{tabular}{|c|c|c|c|c|c|c|}
\hline & \multicolumn{6}{|c|}{ Geographical areas } \\
\hline & \multicolumn{2}{|c|}{ North } & \multicolumn{2}{|c|}{ Center } & \multicolumn{2}{|c|}{ South } \\
\hline & Ancovinto & Cancosa & Cáhuil & Faro & Regalona & Villarrica \\
\hline Moisture & $7.74 \pm 0.07 \mathrm{a}$ & $9.29 \pm 0.06 b$ & $13.17 \pm 0.02 \mathrm{c}$ & $13.17 \pm 0.10 \mathrm{c}$ & $14.27 \pm 0.03 \mathrm{~d}$ & $15.18 \pm 0.02 \mathrm{e}$ \\
\hline Ash & $3.36 \pm 0.06 a$ & $3.46 \pm 0.10 \mathrm{ab}$ & $3.15 \pm 0.07 \mathrm{c}$ & $3.53 \pm 0.04 \mathrm{bd}$ & $3.61 \pm 0.09 \mathrm{~d}$ & $3.65 \pm 0.09 \mathrm{~d}$ \\
\hline Protein $(\mathrm{N} \times 6.25)$ & $12.85 \pm 0.28 \mathrm{a}$ & $13.59 \pm 0.08 b$ & $11.41 \pm 0.54 \mathrm{c}$ & $11.32 \pm 0.19 \mathrm{c}$ & $14.66 \pm 0.38 \mathrm{~d}$ & $16.10 \pm 0.14 \mathrm{e}$ \\
\hline Fat & $6.24 \pm 0.06 \mathrm{a}$ & $5.88 \pm 0.13 b$ & $7.15 \pm 0.16 \mathrm{c}$ & $6.59 \pm 0.10 \mathrm{~d}$ & $6.42 \pm 0.09 \mathrm{ad}$ & $5.97 \pm 0.07 \mathrm{e}$ \\
\hline Crude fiber & $1.45 \pm 0.06 \mathrm{a}$ & $1.91 \pm 0.28 b$ & $1.33 \pm 0.46 \mathrm{a}$ & $1.50 \pm 0.14 \mathrm{a}$ & $1.90 \pm 0.23 b$ & $2.81 \pm 0.07 \mathrm{c}$ \\
\hline Total carbohydrates & $68.36 \pm 0.42 \mathrm{a}$ & $65.88 \pm 0.08 b$ & $63.80 \pm 0.68 c$ & $63.89 \pm 0.17 \mathrm{c}$ & $59.14 \pm 0.27 d$ & $56.73 \pm 0.19 \mathrm{e}$ \\
\hline
\end{tabular}




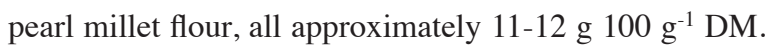
However, quinoa protein content from all the areas is higher compared with cereal flours, such as rice, maize,

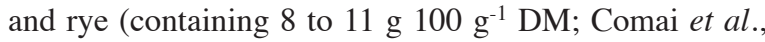
2007). Quinoa seeds contained from 5.88 to $7.15 \mathrm{~g} 100$ $\mathrm{g}^{-1} \mathrm{DM}$ fat. This lipid content makes it a high quality edible vegetable oil similar to soybean oil in its fatty-acid composition (Jancurová et al., 2009); however, it is higher than that of cereals such as corn. The Villarrica ecotype has significantly higher crude fiber $\left(2.80 \mathrm{~g} 100 \mathrm{~g}^{-1} \mathrm{DM}\right)$ content as compared with the other five ecotypes $(<1.9$ g $100 \mathrm{~g}^{-1} \mathrm{DM}$ ) with values similar to those reported by Jancurová et al. (2009). As expected, the highest water activity $\left(a_{w}\right)$ was found in the Regalona ecotype (Table 2), while northern ecotypes showed the lowest $\mathrm{a}_{\mathrm{w}}$ value (also lower moisture content). Since all quinoa seeds showed an $a_{w}<0.5$, they are relatively stable and less susceptible to spoilage during storage, except for Regalona that could be susceptible to microbial spoilage as well as enzymatic oxidation reactions (Barbosa-Canovas and Vega-Mercado, 2000). In addition, a lower difference is observed in acidity and $\mathrm{pH}$ values among the six analyzed ecotypes. These values are important when preparing quinoa flour as a dough additive as it has been suggested for other grain crops (Larsson, 2002).

Mineral contents of quinoa ecotypes are shown in Table 3 . The six quinoa ecotypes contain more $\mathrm{Ca}, \mathrm{Mg}$, $\mathrm{Fe}$, and $\mathrm{P}$ than wheat, barley, oat, rye, or rice (RepoCarrasco et al., 2003). The data obtained for $\mathrm{Mn}, \mathrm{Cu}$, and $\mathrm{Zn}$ in this study are in the range of the values reported by Koziol (1992). Mineral contents compared with data by Ruales and Nair (1993) were found to have lower values for $\mathrm{Ca}, \mathrm{Mg}$, and $\mathrm{Na}$, but higher values for $\mathrm{K}$. The highest $\mathrm{Ca}$ content was found in the Villarrica ecotype, which also had the lowest $\mathrm{P}$ content. Potassium was the most abundant in the Cancosa ecotype and P in the Ancovinto ecotype, both from the northern area, whereas higher $\mathrm{Mn}$ values were found in the central area. Zinc content was significantly higher in the southern area. This may occur because of the soil type and mineral composition of the areas and/or fertilizer application. Heavy doses of $\mathrm{P}$ and $\mathrm{K}$ are known to increase vegetative growth without increasing seed yield (Bhargava et al., 2006), and a high $\mathrm{K}$ content can be beneficial in the diets of people who take diuretics to control hypertension and suffer from excessive $\mathrm{K}$ excretion (Dini et al., 2005). Iron content was also high for the Cancosa ecotype. It is known that iron deficiency anemia (IDA) has been linked to maternal and perinatal mortality, and to impair cognitive skills and physical activity (Ortiz-Monasterio et al., 2007). Iron content in all ecotypes is comparable to wheat, barley, oats, and rice (Repo-Carrasco et al., 2003). It is noteworthy that $\mathrm{Na}$ content showed low values in all ecotypes and even in northern ecotypes. Quinoa plants can concentrate or exclude salt from roots and leaves (Ruiz-Carrasco et al., 2011), but they do not seem to translocate Na to the grains. This is important and it can be suggested that a diet with quinoa provides more health benefits than other saltier foods or cereals. In accordance with this fact, the Villarrica ecotype, followed by Regalona, exhibited the best mineral balance. Zinc content ranged from 2.73 to $5.01 \mathrm{mg} 100$ $\mathrm{g}^{-1} \mathrm{DM}$ and showed no significant differences $(\mathrm{P}>0.05)$ between the Ancovinto, Cáhuil, and Faro ecotypes. The Villarrica ecotype had the highest value and was similar to values obtained by Fardet et al . (2008) for wheat, oat, barley, and rye. Copper content values were higher than those found by Fardet et al. (2008) for oat and barley.

Table 4 shows vitamin contents $\left(C, B_{1}, B_{2}, B_{3}\right.$, and E) of the six quinoa ecotypes from the three different areas. Vitamin $\mathrm{C}$ was higher in the Villarrica ecotype

Table 2. Water activity, pH, and acidity of six quinoa ecotypes from three geographical areas of Chile.

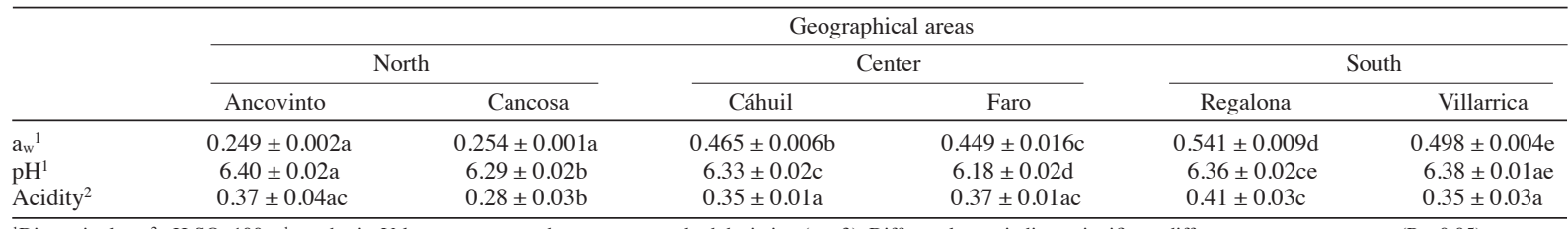

${ }^{1}$ Dimensionless; ${ }^{2} \mathrm{~g} \mathrm{H}_{2} \mathrm{SO}_{4} 100 \mathrm{~g}^{-1}$ wet basis. Values are expressed as mean \pm standard deviation $(\mathrm{n}=3)$. Different letters indicate significant differences among ecotypes $(\mathrm{P}<0.05)$.

Table 3. Mineral content of six quinoa ecotypes from three geographical areas of Chile.

\begin{tabular}{|c|c|c|c|c|c|c|}
\hline & \multicolumn{6}{|c|}{ Geographical areas } \\
\hline & \multicolumn{2}{|c|}{ North } & \multicolumn{2}{|c|}{ Center } & \multicolumn{2}{|c|}{ South } \\
\hline & Ancovinto & Cancosa & Cáhuil & Faro & Regalona & Villarrica \\
\hline $\mathrm{Ca}$ & $77.10 \pm 2.25 \mathrm{a}$ & $105.01 \pm 4.56 \mathrm{~b}$ & $120.33 \pm 1.55 c$ & $121.39 \pm 3.74 \mathrm{c}$ & $118.08 \pm 5.93 c$ & $211.29 \pm 0.35 \mathrm{~d}$ \\
\hline $\mathrm{Mg}$ & $152.31 \pm 0.44 a$ & $150.91 \pm 0.54 \mathrm{a}$ & $160.55 \pm 0.72 b$ & $166.74 \pm 0.22 \mathrm{c}$ & $155.77 \pm 1.36 \mathrm{~d}$ & $160.44 \pm 0.19 b d$ \\
\hline $\mathrm{Na}$ & $<0.01 \pm 0.00 \mathrm{a}$ & $<0.01 \pm 0.00 \mathrm{a}$ & $18.46 \pm 11.68 b$ & $17.14 \pm 0.70 b$ & $19.58 \pm 3.19 b$ & $23.41 \pm 1.08 \mathrm{~b}$ \\
\hline $\mathrm{K}$ & $2188.54 \pm 0.67 a$ & $2325.56 \pm 12.22 \mathrm{a}$ & $1672.79 \pm 0.56 b$ & $1774.43 \pm 11.89 b$ & $2038.42 \pm 10.88 \mathrm{c}$ & $2243.99 \pm 37.49 \mathrm{ac}$ \\
\hline $\mathrm{Fe}$ & $6.91 \pm 0.31 \mathrm{a}$ & $7.19 \pm 0.15 a$ & $5.06 \pm 0.03 b$ & $5.84 \pm 0.08 \mathrm{c}$ & $7.03 \pm 0.26 a$ & $4.82 \pm 0.28 b$ \\
\hline $\mathrm{Cu}$ & $1.52 \pm 0.20 \mathrm{a}$ & $0.75 \pm 0.00 b$ & $0.86 \pm 0.04 \mathrm{ab}$ & $0.89 \pm 0.02 \mathrm{ab}$ & $0.95 \pm 0.02 \mathrm{ab}$ & $0.89 \pm 0.02 b$ \\
\hline $\mathrm{Mn}$ & $2.39 \pm 0.02 \mathrm{a}$ & $2.36 \pm 0.02 \mathrm{a}$ & $6.47 \pm 0.17 b$ & $5.73 \pm 0.08 c$ & $4.67 \pm 0.15 \mathrm{~d}$ & $2.76 \pm 0.19 \mathrm{e}$ \\
\hline $\mathrm{Zn}$ & $3.75 \pm 0.22 \mathrm{a}$ & $3.10 \pm 0.03 b$ & $4.02 \pm 0.17 \mathrm{a}$ & $2.73 \pm 0.01 \mathrm{a}$ & $4.65 \pm 0.06 \mathrm{c}$ & $5.01 \pm 0.38 \mathrm{~d}$ \\
\hline $\mathrm{P}$ & $526.36 \pm 3.79 \mathrm{a}$ & $434.65 \pm 14.27 b$ & $409.92 \pm 8.42 b$ & $480.96 \pm 2.62 \mathrm{c}$ & $353.53 \pm 10.88 \mathrm{~d}$ & $285.06 \pm 65.81 \mathrm{e}$ \\
\hline
\end{tabular}

All data are expressed as $\mathrm{mg} 100 \mathrm{~g}^{-1} \mathrm{DM}$. Values are expressed as mean \pm standard deviation $(\mathrm{n}=3)$. Different letters indicate significant differences among ecotypes $(\mathrm{P}<0.05)$. 
Table 4. Vitamin content of six quinoa ecotypes from three geographical areas of Chile.

\begin{tabular}{|c|c|c|c|c|c|c|}
\hline & \multicolumn{6}{|c|}{ Geographical areas } \\
\hline & \multicolumn{2}{|c|}{ North } & \multicolumn{2}{|c|}{ Center } & \multicolumn{2}{|c|}{ South } \\
\hline & Ancovinto & Cancosa & Cáhuil & Faro & Regalona & Villarrica \\
\hline Vitamin C & $16.702 \pm<0.001 \mathrm{a}$ & $16.204 \pm 1.116 \mathrm{a}$ & $13.889 \pm 1.118 b$ & $12.402 \pm 1.117 \mathrm{~b}$ & $17.011 \pm 1.121 \mathrm{a}$ & $23.065 \pm 1.119 \mathrm{c}$ \\
\hline Vitamin $B_{1}$ & $0.452 \pm 0.018 \mathrm{a}$ & $0.485 \pm 0.006 b$ & $0.562 \pm 0.017 \mathrm{c}$ & $0.558 \pm 0.027 \mathrm{c}$ & $0.648 \pm 0.006 \mathrm{~d}$ & $0.349 \pm 0.006 \mathrm{e}$ \\
\hline Vitamin $B_{2}$ & $0.081 \pm 0.002 \mathrm{a}$ & $0.073 \pm 0.002 b$ & $0.067 \pm 0.002 \mathrm{c}$ & $0.060 \pm 0.005 \mathrm{~d}$ & $0.056 \pm 0.002 \mathrm{e}$ & $0.074 \pm 0.001 b$ \\
\hline Vitamin $B_{3}$ & $0.994 \pm 0.046 \mathrm{a}$ & $0.562 \pm 0.013 b$ & $1.303 \pm 0.051 \mathrm{c}$ & $1.226 \pm 0.056 \mathrm{~d}$ & $1.569 \pm 0.026 \mathrm{e}$ & $1.418 \pm 0.005 f$ \\
\hline Vitamin E & $2.465 \pm 0.184 a$ & $2.587 \pm 0.108 \mathrm{a}$ & $2.613 \pm 0.039 a$ & $3.051 \pm 0.079 \mathrm{~b}$ & $2.445 \pm 0.082 \mathrm{a}$ & $4.644 \pm 0.240 \mathrm{c}$ \\
\hline
\end{tabular}

All data are expressed as mg $100 \mathrm{~g}^{-1} \mathrm{dm}$. Values are expressed as mean \pm standard deviation $(\mathrm{n}=3)$. Different letters indicate significant differences among ecotypes $(\mathrm{P}<0.05)$.

with significant differences $(\mathrm{P}<0.05)$ compared with the rest of the ecotypes. The Faro ecotype had significantly lower vitamin $\mathrm{C}$ content than the other ecotypes. The variations among ecotypes for vitamin $\mathrm{C}$ content are due to the biological diversity of quinoa ecotypes in Chile. According to Jiménez et al. (2009), variations can be attributed to genetic or environmental growth conditions. Lee and Kader (2000) reported that some citrus fruit contained more vitamin $\mathrm{C}$ when grown under cool temperatures rather than hot temperatures. The vitamin $\mathrm{C}$ content found in this investigation was similar to other data reported by Ruales and Nair (1993) for quinoa seed (16.4 mg AA $100 \mathrm{~g}^{-1} \mathrm{DM}$ ) and Dini et al. (2010), who worked with quinoa from Ecuador and Peru (13.0 and $12.0 \mathrm{mg}$ AA $100 \mathrm{~g}^{-1} \mathrm{DM}$, respectively). Lower values of vitamin $\mathrm{C}$ have also been reported in the literature by Koziol (1992) (4 to $5 \mathrm{mg}$ AA $100 \mathrm{~g}^{-1} \mathrm{DM}$ ). Vitamin C losses increase with extended storage, higher temperature, low relative humidity, physical damage, chilling injury, large genotypic variation, and climatic conditions; all these factors are responsible for the wide variation in vitamin C content (Lee and Kader, 2000; Dumas et al., 2003; Xu et al., 2008). Wall (2006), in his work with fruit ecotypes grown in Hawaii, commented that ascorbic acid levels in fruit are influenced by the availability of light to the crop and to individual fruits. In addition, an excess of soil $\mathrm{N}$ or $\mathrm{P}$ tends to decrease ascorbic acid content in fruit, while an excess of $\mathrm{K}$ could increase vitamin $\mathrm{C}$ content.

The B-group vitamins are water-soluble molecules and play an important metabolizing role, particularly in the metabolism of carbohydrates (thiamine or $\mathrm{B}_{1}$ ), proteins, and fats (riboflavin or $\mathrm{B}_{2}$, and pyridoxine). Table 4 shows vitamin $\mathrm{B}_{1}, \mathrm{~B}_{2}$, and $\mathrm{B}_{3}$ contents in the quinoa ecotypes. Vitamin $\mathrm{B}_{1}$ content was the highest in the Regalona seeds (hybrid variety) probably because of a generally better soil quality in southern Chile and with higher organic matter content as compared with soils of the drier northern areas, which is a typical condition of arid zones (FernándezCirelli et al., 2009). There were no significant differences $(\mathrm{P}>0.05)$ in vitamin $\mathrm{B}_{1}$ content between central area ecotypes. Vitamin $\mathrm{B}_{1}$ content is comparable to values of $0.38 \mathrm{mg} 100 \mathrm{~g}^{-1} \mathrm{DM}$ by Koziol (1992) and $0.4 \mathrm{mg} 100 \mathrm{~g}^{-1}$ DM by Ruales and Nair (1993). Batifoulier et al. (2006) reported values for vitamin $\mathrm{B}_{1}$ that ranged from 0.259 to $0.613 \mathrm{mg} 100 \mathrm{~g}^{-1} \mathrm{DM}$ for 49 northwestern European wheat ecotypes, while Lebiedzińska and Szefer (2006) reported values from 0.344 to $0.369 \mathrm{mg} 100 \mathrm{~g}^{-1} \mathrm{DM}$ for barley. Vitamin $\mathrm{B}_{2}$ values are much lower than those reported by Koziol (1992) and Ruales and Nair (1993) with 0.39 $\mathrm{mg}$ to $0.2 \mathrm{mg} 100 \mathrm{~g}^{-1} \mathrm{DM}$. Vitamin $\mathrm{B}_{3}$ (niacin) supply is low on quinoa ecotypes, even lower than those reported by Lebiedzińska and Szefer (2006) on brown rice and

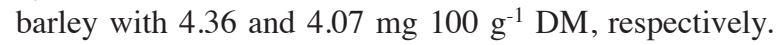
Koziol (1992) reported $1.06 \mathrm{mg} 100 \mathrm{~g}^{-1} \mathrm{DM}$ for quinoa $\mathrm{B}_{3}$ content. Batifoulier et al. (2006) reported significant differences in vitamin B contents in wheat due to variety, growing location (for thiamine and riboflavin), soil type, and years (for thiamine and pyridoxine).

Vitamin E is a well-known antioxidant that acts as a free scavenger by preventing the oxidation of polyunsaturated lipids by free radicals such as the hydroxyl radical $\mathrm{OH}$ (Fardet et al., 2008). As shown in Table 4, quinoa vitamin E values ranged from 2.44 to $4.64 \mathrm{mg} 100 \mathrm{~g}^{-1} \mathrm{DM}$ with the Villarrica ecotypes showing the highest value. Similar levels of vitamin E were reported by Koziol (1992) for

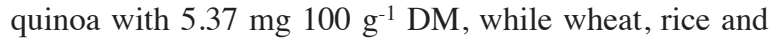
barley had lower values $(1.15 \mathrm{mg}, 0.18 \mathrm{mg}$, and $0.35 \mathrm{mg}$ $100 \mathrm{~g}^{-1} \mathrm{DM}$, respectively).

Figure 1 shows that the saponin content was significantly different $(\mathrm{P}<0.05)$ among quinoa ecotypes; it ranged from $0.84 \%$ to $3.91 \%$ DM for the Villarrica and Cáhuil ecotypes, respectively. Analysis of saponin content in quinoa ecotypes indicates that variability among ecotypes is important. Nevertheless, abrasive procedures to remove saponin might cause nutrient losses such as $\mathrm{Ca}$, but they have no effects on $\mathrm{P}, \mathrm{K}$, and $\mathrm{Mg}$ localized in the seed embryo or on some vitamins because they are found

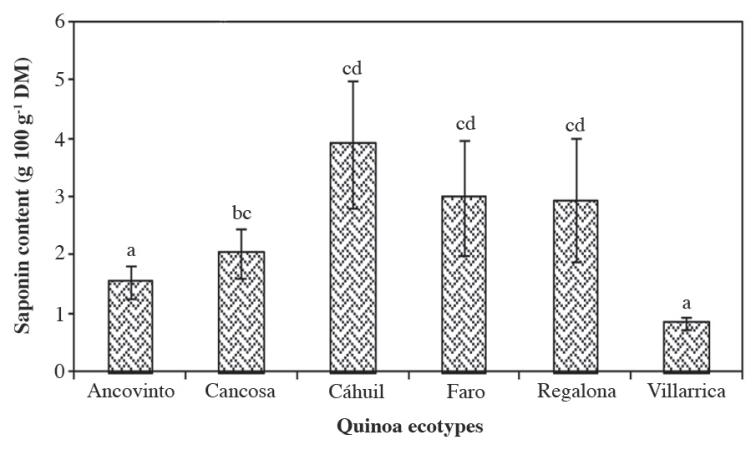

Distinct letters over the bars indicate differences according to Fisher's test $(\mathrm{P}<0.05)$.

Figure 1. Saponin content of six quinoa ecotypes from three geographical areas of Chile. 
in the grain pericarp (Konishi et al., 2004). Saponins are also considered as important sources of health benefits such as decreasing cholesterol levels (Kuljanabhagavad et al., 2008), and the methods to remove them are being improved (Quispe-Fuentes et al., 2012).

The overall nutritional and mineral dataset used to plot the first and second main axes of the Principal Component Analysis (Figure 2) clearly separated the three geographical sources of quinoa used in this study. In addition, there is a clear separation between Regalona and Villarrica, because of the hybrid state of Regalona. The overall picture also correlates well with the genetic differences previously observed among quinoa ecotypes of the country's three regions (Fuentes et al., 2012).

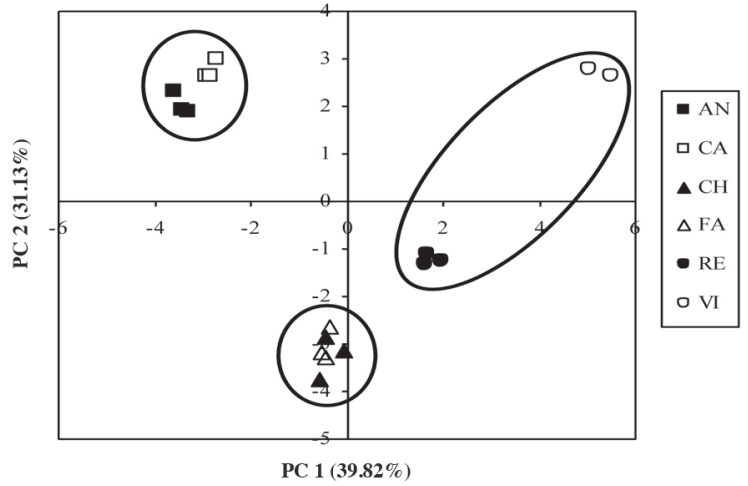

Figure 2. Two main axes of the Principal Component Analysis constructed from the overall set of 24 measured nutritional values applied to the three samples of each quinoa origin where open ovals enclose the three main geographical origins: Squares represent the High Plateau (two localities, AN: Ancovinto, CA: Cancosa), triangles represent the Center (two localities, FA: Faro, CH: Cáhuil), and circles represent the South (one locality, VI: Villarrica, and one hybrid variety, RE: Regalona).

\section{CONCLUSIONS}

The rich seed diversity of quinoa ecotypes produced in different biogeographical areas of Chile also differed in their nutritional properties, minerals, vitamins, and saponin contents, thus in their nutritional value. However, all ecotypes showed an outstanding nutritional quality, higher than that of most traditional cereals. Such nutritional and chemical features of quinoa seeds from very diverse geographical areas offer excellent opportunities for genetic improvement trials and the creation of new and better varieties to solve crop adaptation problems to places where climatic and soil conditions are limiting for other crops, particularly in regions of the world where hunger is still an unsolved issue. More related studies are needed to confirm particular properties of quinoa from specific areas, for instance locality-related observed differences in $\mathrm{Ca}, \mathrm{Fe}, \mathrm{Na}$, or protein contents. This could help to coin the term of controlled designation of origin (appellation d'origine contrôlée), which could add commercial value to the Chilean quinoa seeds in the domestic and international markets.

\section{ACKNOWLEDGEMENTS}

The authors gratefully acknowledge the financial support from project FONDECYT 1100638 and the Research Department of the Universidad de La Serena (DIULS), Chile.

Aspectos nutricionales de seis ecotipos de quínoa (Chenopodium quinoa Willd.) de tres zonas geográficas de Chile. La diversidad en el cultivo de la quínoa (Chenopodium quinoa Willd.) de Chile fue explorada desde una perspectiva nutricional. En este contexto las propiedades nutricionales como también los contenidos de minerales, vitaminas y saponina fueron evaluados en las semillas de seis ecotipos chilenos de quínoa, cultivados en las tres principales zonas de producción con condiciones edafoclimáticas distintas: Ancovinto y Cancosa del altiplano del norte, Cáhuil y Faro de la zona costera central y, Regalona y Villarrica en el sur del país. Hubo diferencias significativas $(\mathrm{P}<0.05)$ en todas las propiedades nutricionales de las semillas de todas las zonas. El ecotipo Villarrica tenía el mayor contenido de proteína (16.10 g $\left.100 \mathrm{~g}^{-1} \mathrm{MS}\right)$ y de vitamina E y C (4.644 \pm 0.240 y $23.065 \pm$

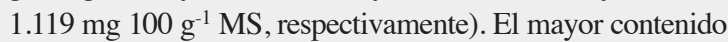
de vitamina B1 $\left(0.648 \pm 0.006 \mathrm{mg} 100 \mathrm{~g}^{-1} \mathrm{MS}\right)$ y B3 $(1.569 \pm$ $\left.0.026 \mathrm{mg} 100 \mathrm{~g} \mathrm{~g}^{-1} \mathrm{MS}\right)$ fue encontrado en el ecotipo Regalona, y el mayor contenido de vitamina B2 $(0.081 \pm 0.002 \mathrm{mg} 100$ $\mathrm{g}^{-1} \mathrm{MS}$ ) en el ecotipo Ancovinto. El $\mathrm{K}$ fue el mineral más abundante con un valor de $2325.56 \mathrm{mg} 100 \mathrm{~g}^{-1} \mathrm{MS}$ en el ecotipo Cancosa. El contenido de saponina fluctuó entre 0.84

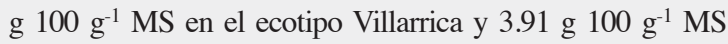
en el ecotipo Cáhuil. Hubo diferencias significativas entre los ecotipos chilenos de quínoa cultivados bajo diferentes condiciones climáticas. No obstante, las semillas de quinoa de cualquier zona demuestran un alto valor nutricional. Estos resultados son relevantes en el sentido que se puede afirmar que la quinoa tiene propiedades típicas de la zona de cultivo. Los resultados obtenidos son coincidentes con diferencias genéticas observadas previamente entre las tres localidades muestreadas. Si se agregan más estudios de este tipo podría acuñarse el término de "denominación de origen controlado" (appellation d'origine contrôlée) y dar un valor agregado a las semillas de quínoa de Chile tanto en el mercado nacional como internacional.

Palabras clave: quínoa, vitaminas, minerales, contenido de saponina, propiedades nutricionales.

\section{LITERATURE CITED}

AOAC. 1990. Official method of analysis. $15^{\text {th }}$ ed. Association of Official Analytical Chemists (AOAC), Washington, DC, USA. AOAC. 1995. Official method of analysis. $16^{\text {th }}$ ed. Association of Official Analytical Chemists (AOAC), Washington, DC, USA.

Barbosa-Canovas, G.V., and H. Vega-Mercado. 2000. Deshidratación de alimentos. Editorial ACRIBIA S.A., Zaragoza, España.

Barakat, M.Z., M.F.A. El-Wahab, and M.M.El-Sadr. 1955. Action of N-bromosuccinimide on ascorbic acid. Biochemistry Department, Faculty of Medicine, Abbassia, Cairo, Egypt. Analytical Chemistry 27:536-540. 
Barikmo, I., F. Ouattarab, and A. Oshaug. 2004. Protein, carbohydrate and fibre in cereals from Mali - how to fit the results in a food composition table and database. Journal of Food Composition and Analysis 17:291-300.

Batifoulier, F., M.A. Verny, E. Chanliaud, C. Rémésy, and C. Demigné. 2006. Variability of B vitamin concentrations in wheat grain, milling fractions and bread products. European Journal of Agronomy 25:163-169.

Bhargava, A., S. Shukla, and D. Ohri. 2006. Chenopodium quinoa: an Indian perspective. Industrial Crops and Products 23:73-87.

Capriles, V.D., K.D. Coelho, A.C. Guerra-Matías, and J.A.G. Arêas. 2008. Effects of processing methods on amaranth starch digestibility and predicted glycemic Index. Journal of Food Science 73:H160-H164.

Chapagain, A.K., and A.Y. Hoekstra. 2008. The global component of freshwater demand and supply: An assessment of virtual water flows between nations as a result of trade in agricultural and industrial products. Water International 33:19-32.

Comai, S., A. Bertazzo, L. Bailoni, M. Zancato, C.V.L. Coata, and G. Allegri. 2007. The content of proteic and nonproteic (free and protein-bound) tryptophan in quinoa and cereal flours. Food Chemistry 100:1350-1355.

Dini, I., G.C. Tenore, and A. Dini. 2005. Nutritional and antinutritional composition of Kancolla seeds: an interesting and underexploited Andine food plant. Food Chemistry 92:125-132.

Dini, I., G.C. Tenore, and A. Dini. 2010. Antioxidant compound contents and antioxidant activity before and after cooking in sweet and bitter Chenopodium quinoa seeds. LWT- Food Science and Technology 43:447-451.

Dumas, Y., M. Dadomo, G. Di Lucca, and P. Grolier. 2003. Review: Effects of environmental factors and agricultural techniques on antioxidant content of tomatoes. Journal of the Science of Food and Agriculture 83:369-382.

FAO. 2011. The state of food and agriculture. 147 p. Food and Agriculture Organization of the United Nations, Rome, Italy.

Fardet, A., E. Rock, and C. Rémésy. 2008. Is the in vitro antioxidant potential of whole-grain cereals and cereal products well reflected in vivo? Journal of Cereal Science 48:258-276.

Fernández-Cirelli, A., J.L. Arumí, D. Rivera, and P.W. Boochs. 2009. Environmental effects of irrigation in arid and semi-arid Regions. Chilean Journal of Agricultural Research 69:27-40.

Fuentes, F.F., D. Bazile, A. Bhargava, and E.A. Martínez. 2012. Implications of farmers' seed exchanges for on-farm conservation of quinoa, as revealed by its genetic diversity in Chile. Journal of Agricultural Science. doi:10.1017/S0021859612000056.

Fuentes, F.F., E.A. Martinez, P.V. Hinrichsen, E.N. Jellen, and P.J. Maughan. 2009. Assessment of genetic diversity patterns in Chilean quinoa (Chenopodium quinoa Willd.) germplasm using multiplex fluorescent microsatellite markers. Conservation Genetics 10:369-377.

Galdón, B.R., D.R. Mesa, E.R. Rodríguez, and C.D. Romero. 2010. Influence of the cultivar on the organic acid and sugar composition of potatoes. Journal of the Science of Food and Agriculture 90:2301-2309.

Hirose, Y., T. Fujita, T. Ishii, and N. Ueno. 2010. Antioxidative properties and flavonoid composition of Chenopodium quinoa seeds cultivated in Japan. Food Chemistry 119:1300-1306.

Huygens, D., P. Boeckx, L. Templer, O. Paulino, C. Van Cleemput, C. Oyarzún, et al. 2008. Mechanisms for retention of bioavailable nitrogen in volcanic rainforest soils. Nature Geoscience 1:543-548.

Jancurová, M., L. Minarovicová, and A. Dandar. 2009. Quinoa - A review. Czech Journal of Food Sciences 27:71-79.

Jiménez, M.E., A.M. Rossi, and N.C. Sammán. 2009. Phenotypic, agronomic and nutritional characteristics of seven varieties of Andean potatoes. Journal of Food Composition and Analysis 22:613-616.

Konishi, Y., S. Hirano, H. Tsuboi, and M. Wada. 2004. Distribution of minerals in quinoa (Chenopodium quinoa Willd.) seeds. Bioscience, Biotechnology, and Biochemistry 68:231-234.

Kozioł, M.J. 1992. Chemical composition and nutritional evaluation of quinoa (Chenopodium quinoa Willd.) Journal of Food Composition and Analysis 5:35-68.
Kuljanabhagavad, T., P. Thongphasuk, W. Chamulitrat, and M. Wink. 2008. Triterpene saponins from Chenopodium quinoa Willd. Phytochemistry 69:1919-1926.

Larsson, H. 2002. Effect of $\mathrm{pH}$ and sodium chloride on wheat flour dough properties: Ultracentrifugation and rheological measurements. Cereal Chemistry 79:544-545.

Lebiedzińska, A., and P. Szefer. 2006. Vitamins B in grain and cerealgrain food, soy-products and seeds. Food Chemistry 95:116-122.

Lee, S.K., and A.A. Kader. 2000. Preharvest and postharvest factors influencing vitamin $\mathrm{C}$ content of horticultural crops. Postharvest Biology and Technology 20:207-220.

Martínez, E.A., E. Veas, C. Jorquera, R. San Martín, and P. Jara. 2009. Re-introduction of Chenopodium quinoa Willd. into arid Chile: Cultivation of two lowland races under extremely low irrigation. Journal of Agronomy and Crop Science 195:1-10.

Miranda, M., A. Vega-Gálvez, J. López, G. Parada, M. Sanders, M. Aranda, et al. 2010. Impact of air-drying temperature on nutritional properties, total phenolic content and antioxidant capacity of quinoa seeds (Chenopodium quinoa Willd.) Industrial Crops and Products 32:258-263.

Ortiz-Monasterio, J.I., N. Palacios-Rojas, E. Meng, K. Pixley, R. Trethowan, and R.J. Peña. 2007. Enhancing the mineral and vitamin content of wheat and maize through plant breeding. Journal of Cereal Science 46:293-307.

Quispe-Fuentes, I., A. Vega-Gálvez, M. Miranda, R. LemusMondaca, M. Lozano and K. Ah-Hen. 2012. a kinetic approach to saponin extraction during washing of quinoa (Chenopodium quinoa Willd.) seeds. Journal of Food Process Engineering ISSN 1745-4530. doi:10.1111/j.1745-4530.2012.00673.x.

Repo-Carrasco, R., C. Espinoza, and S.E. Jacobsen. 2003. Nutritional value and use of the Andean crops quinoa (Chenopodium quinoa) and kañiwa (Chenopodium pallidicaule). Food Reviews International 19:179-189.

Repo-Carrasco-Valencia, R., J.K. Hellstrom, J.M. Pihlava, and P.H. Mattila. 2010. Flavonoids and other phenolic compounds in Andean indigenous grains: Quinoa (Chenopodium quinoa), kañiwa (Chenopodium pallidicaule) and kiwicha (Amaranthus caudatus). Food Chemistry 120:128-133.

Ruales, J., and B.M. Nair. 1993. Contents of fat, vitamins and minerals in quinoa (Chenopodium quinoa Willd.) seeds. Food Chemistry 48:131-137.

Ruiz, R.A., and H.D. Bertero. 2008. Light interception and radiation use efficiency in temperate quinoa (Chenopodium quinoa Willd.) ecotypes. European Journal of Agronomy 29:144-152.

Ruiz-Carrasco, K., F. Antognoni, A.K. Coulibaly, S. Lizardi, A. Covarrubias, E.A. Martínez, et al. 2011. Variation in salinity tolerance of four lowland genotypes of quinoa (Chenopodium quinoa Willd.) as assessed by growth, physiological traits, and sodium transporter gene expression. Plant Physiology and Biochemisytry 49:1333-1341.

San Martín, R., and R. Briones. 2000. Quality control of commercial quillay (Quillaja saponaria Molina) extracts by reverse phase HPLC. Journal of the Science of Food and 80:2063-2068

Thybo, A.K., J. Christiansen, K. Kaack, and M.A. Petersen. 2006. Effect of ecotypes, wound healing and storage on sensory quality and chemical components in pre-peeled potatoes. LWT- Food Science and Technology 39:166-176.

Vega-Gálvez, A., M. Miranda, J. Vergara, E. Uribe, L. Puente, and E.A. Martínez. 2010. Nutrition facts and functional potential of quinoa (Chenopodium quinoa Willd.). An ancient Andean grain. A review. Journal of the Science of Food and Agriculture 90:2541-2547.

Xu, S., J. Hu, H. Tan, and S. Zhang. 2008. Effects of genotype and environment on vitamin $\mathrm{C}$ content and its heterosis in towel gourd fruits. Journal of the Science of Food and Agriculture 88:293-293.

Wall, M.M. 2006. Ascorbic acid and mineral composition of longan (Dimocarpus longan), lychee (Litchi chinensis) and rambutan (Nephelium lappaceum) ecotypes grown in Hawaii. Journal of Food Composition and Analysis 19:655-663.

Wright, K.H., O.A. Pike, D.J. Fairbanks, and S.C. Huber. 2002. Composition of Atriplex hortensis, sweet and bitter Chenopodium quinoa seeds. Food and Chemical Toxicology 67:1383-1385. 